\title{
災害監視を目的とした屋外型飛行船ロボットの経路追従制御*
}

\author{
佐伯 一夢 ${ }^{* 1}$, 深尾 隆則 ${ }^{* 1}$, 浦久保 孝光 ${ }^{* 2}$, 河野 敬 ${ }^{* 3}$
}

\section{A Path Following Control of Outdoor Blimp Robots for Disaster Surveillance}

\author{
Hitomu SAIKI ${ }^{*}$, Takanori FUKAO, Takateru URAKUBO and Takashi KOHNO \\ ${ }^{* 1}$ Graduate School of Engineering, Kobe University \\ 1-1 Rokkodai-cho, Nada-ku, Kobe, Hyogo 657-8501 Japan
}

\begin{abstract}
A surveillance system has been required to gather information after large-scale disasters on stricken areas safely and quickly. To collect the information, it is useful to use a blimp, because of its low-sky availability, safety and long flight. A blimp flying at low altitude can capture high quality images offering 3D imagery in disasters. This paper proposes a new path following control method for outdoor blimp robots under windy conditions to collect detailed disaster information. The method consists of path following control in the wind coordinate on the horizontal plane and altitude control on the longitudinal plane. And this method minimizes the lateral errors arising from the wind disturbances considering path regeneration. Some simulations and experiments for a $12 \mathrm{~m}$ class blimp are performed to confirm the usefulness of the proposed method.
\end{abstract}

Key Words : Underactuated Outdoor Blimp Robot, Path Following Control, Path Regeneration, Wind Disturbances, Rescue

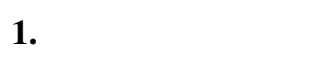

阪神淡路大震災，アメリカ同時テロを契機に，災害後のレスキュー活動におけるロボットの必要性が認識され， 迅速な状況把握と救援活動計画策定のために，詳細な情報を確実に自動収集するシステムが必要とされている.特 に地震災害においては，瓦礫に埋もれた被災者の生存率が 72 時間を過ぎると急速に低下することが知られてお り ${ }^{(1)}$, 情報収集の遅れが大きな問題となっている.災害発生時には道路の寸断や交通渋滞の影響により，地上に おける情報収集活動には限界がある .

このため, 上空からの詳細な状況把握が非常に重要であり, 特にUAV(Unmanned Aerial Vehicle) システムは広 域での効率的な活動に有望であるため, 自律型のへリコプタや飛行機に関して樣々な研究が行われている.この ような航空機に対し，飛行船は浮揚ガスによる浮力を利用して飛行するため，急に墜落する可能性が極めて低く， 被災者に対して相当に安全性が高い，さらに輸送効率が高く，航続時間も長いため，広範な災害地域において滞 空，低速，低空飛行することが可能である．

これらの利点に注目し, 本研究グループでは自律型飛行船を用いる災害監視システムを提案している ${ }^{(2)}$. 自律 型の無人飛行船を用いた先行プロジェクトもすでに世界各国で活発に行われており，飛行船の特性 ${ }^{(3)}$ を生かしたさ まざまな活用分野が期待されている. DGPS による飛行船のナビゲーション戦略に関するブラジルの AURORAプ

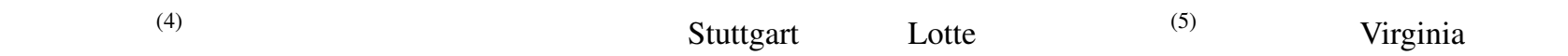

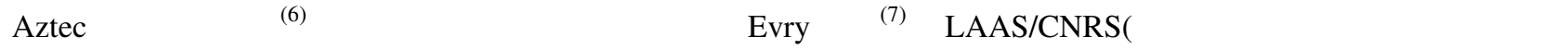

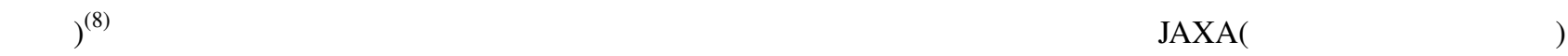

\footnotetext{
* 原稿受付 2012 年 4 月 25 日

*1 正員, 神戸大学大学院工学研究科機械工学専攻（二 $657-8501$ 兵庫県神戸市灘区六甲台町 1-1）

*2 神戸大学大学院システム情報学研究科システム科学専攻

（广657-8501＼cjkstart兵庫県神戸市灘区六甲台町 1-1）

*3 正員, (独) 宇宙航空研究開発機構（干182-8522 東京都調布市深大寺東町 7-44-1）

E-mail: saiki@stu.kobe-u.ac.jp
} 
にて , ミレニアム・プロジェクトとして飛行船を用いた成層圏プラットフォームの研究開発が行われてきた ${ }^{(9)}$.

本システムは災害の直後に，GPS(Grobal Positioning System)の情報をもとに図 1 のような経路上を確実に自律

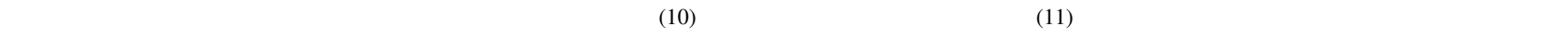
行う. 光して得られたデータを用いて三次元再構成した被災地の情報を，地理情報システム上で提示することを 目的としている．一方で，飛行船はペイロードを確保するために船体が大きくならざるを得ず，飛行時に風の影 響を非常に受けやすい . さらに横方向への移動損失が大きいため, 真横方向への直接的な推力を持たない劣駆動 システムであることが多く，実用化するためには，風に対してロバストな飛行船の経路追従制御法が必要である．

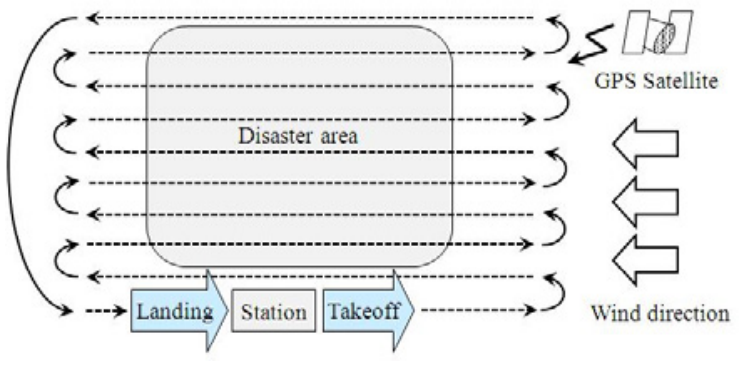

Fig. 1 Flight path for information gathering

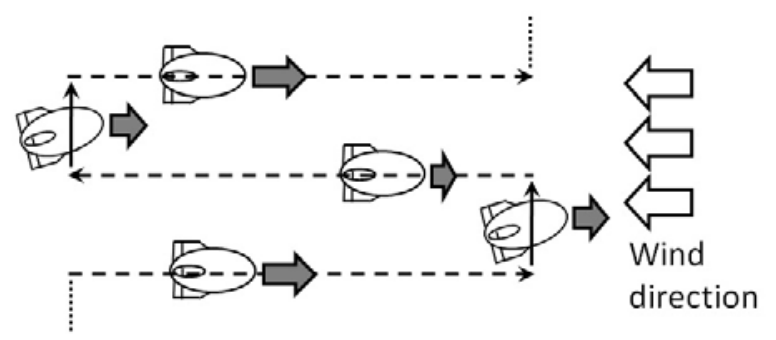

Fig. 2 A new aspect of path following under strong wind

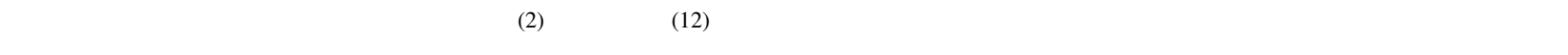
かつ滑らかに経路に復帰できるような飛行船の軌道追従制御手法を提案し，全長 $12 \mathrm{~m}$ 級の屋外型飛行船において $5 \mathrm{~m} / \mathrm{s}$ までの風速下での自動巡回が可能となった . しかしながら，風速 $5 \mathrm{~m} / \mathrm{s}$ 以上の強風時には，これまでの提案手 法では情報収集を行うのに十分な精度が得られていない，また，飛行船の地上に対する移動速度は，抜けのない 情報取得を行うために，5m/s 以下で目標経路に沿って飛行することを想定している．光のため，地上に対する速 度を基に制御する従来の方法では，追い風方向に飛行する際に対気速度が小さくなってしまい，舵が効きづらく 制御性が低くなることがわかった .

乥こで，本論文では風速 $5 \mathrm{~m} / \mathrm{s}$ 以上の強風時に有効となる経路追従制御法を提案する. 提案手法は, 飛行船の制 御において最大の問題となる風をすべて外乱として扱うのではなく，風に座標系をおいた空間 ${ }^{(13)}$ 内で目標経路を 生成して，飛行船の経路追従制御を行うという飛行船に特有な制御法である。この方法によれば，従来手法より も風の影響を小さく扱うことができ, 飛行船に与える目標速度や経路を適切に設定することで, 強風時に図 2 の ような飛行経路での自律飛行が可能となる．このような自律飛行を実現することで，強風時にも風下側への安定 した低速移動が可能となる.さらに，目標経路からの横偏差の大きさに応じて風座標系内で経路再生成を行うこ とで, 飛行船が突風や横風を受けて目標経路を逸脱した場合にも滑らかかつ迅速に経路復帰可能な方法を提案す る、以上の方法により，全長 $12 \mathrm{~m}$ 級の自律型飛行船ロボットを用いて飛行制御実験を行い，本提案手法の強風下 での情報收集飛行に対する有効性について考察する．

\section{2. 情報収集のための経路追従制御}

本章では，広範な災害現場での情報収集を目的とした屋外型飛行船ロボットの経路追従制御について述べる.こ こで想定している制御の目的は，風速 $5 \mathrm{~m} / \mathrm{s}$ 以上の強風下でも，飛行船ロボットを一定の高度に保ちながら，目標 経路に正確に追従させることである . 現在の計測機器類の性能を考慮し，情報收集を行う飛行部分において以下 を目標としている．

- 目標経路からの横方向の誤差を $1 \mathrm{~m}$ 以内に抑える .

・飛行高度は目標值から $5 \mathrm{~m}$ 以内を保ち, 急なピッチング運動を防ぐ .

カメラやレーザスキャナによる計測に影響を与えないためには, 特に水平面内での目標経路への追従性能が重要 となる。 


\section{$2 \cdot 1$ 座標系の定義と運動モデル}

本論文では，飛行船の運動における回転中心と重心が一致すると仮定し，機体に固定した座標系 $(X, Y, Z)$ およ び地球に固定した座標系 $\left(X_{E}, Y_{E}, Z_{E}\right)$ を図 3 のようにとり，機体の回転方向を図のように定義する . また，地球座 標系を基準とした飛行船の姿勢角を $\left[{ }^{E} \phi,{ }^{E} \boldsymbol{\theta},{ }^{E} \boldsymbol{\psi}\right]^{T}$ (ロール角，ピッチ角，ヨー角)，姿勢角速度を $[p, q, r]^{T}$ (ロール角 速度，ピッチ角速度，ヨ一角速度) とし，機体軸における対気速度の各成分を $[u, v, w]^{T}$ とする．

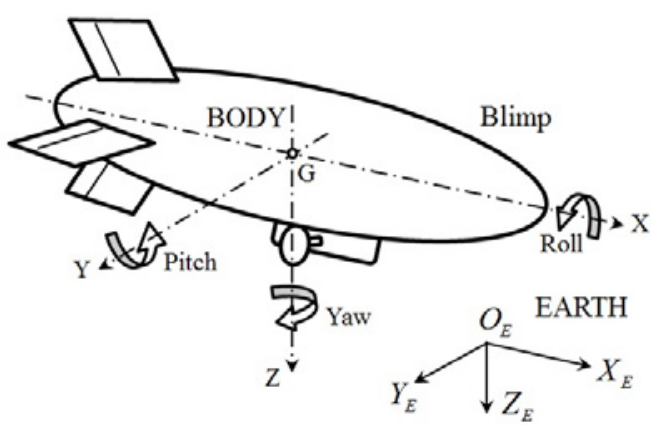

Fig. 3 The body-fixed frame and the earth-fixed frame

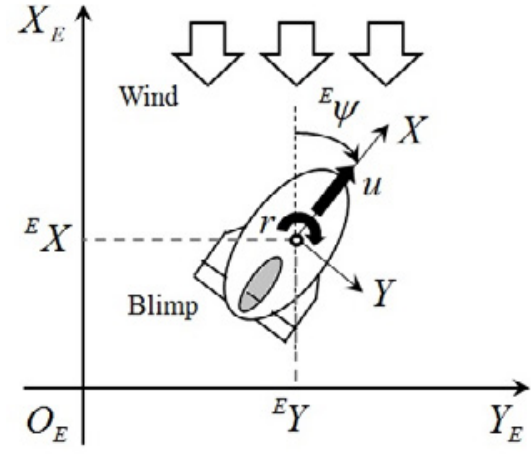

Fig. 4 Configuration of blimp in the horizontal plane

制御系設計にあたり，飛行船の性質より飛行時のローリングおよびピッチング運動の変化が微小かつ安定である と仮定し, 飛行船の運動を水平方向 $O_{E} X_{E} Y_{E}$ 平面内の運動と鉛直方向 $O_{E} X_{E} Z_{E}$ 平面 (以降, 縦方向と呼心) 内の運

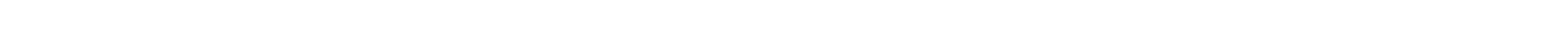
経路に追従させるとともに, 縦方向における高度とピッチング運動を制御する ${ }^{(14)(15)}$. 本論文では, 縦運動の制御 には文献 [15]の手法を用いるものとし，紙面の都合から，水平面方向の制御手法についてのみ示す．

仮定により，分離した飛行船の水平面方向の運動学モデルは次のように表せる．

$$
\begin{aligned}
& { }^{E} \dot{X}=u \cos ^{E} \psi-v \sin ^{E} \psi+W_{x} \\
& { }^{E} \dot{Y}=u \sin ^{E} \psi+v \sin ^{E} \psi+W_{y} \\
& { }^{E} \dot{\psi}=r
\end{aligned}
$$

ここで， $W_{x}, W_{y}$ は，弚れ光れ地球座標系 $X_{E}$ 軸， $Y_{E}$ 軸方向の風速である

本論文では, 地球座標系 $\left(X_{E}, Y_{E}, Z_{E}\right)$ を図 4 の方向，つまり，風上方向に対して $X_{E}$ 軸をとり，この $X_{E}$ 軸に対し て平行に目標経路を設定し，飛行船を追従させることを考える。飛行船が受ける横風成分を $W_{y} \fallingdotseq 0$ と仮定し，飛 行船の劣駆動性から横滑り速度を $v \fallingdotseq 0$ とみなす.さらに $\tilde{W}_{x}$ を $X_{E}$ 軸方向における定常的な一定風速とし , 以下 の運動学モデルを扱う.

$$
\begin{aligned}
& { }^{E} \dot{X}=u \cos { }^{E} \psi+\tilde{W}_{x} \\
& { }^{E} \dot{Y}=u \sin ^{E} \psi \\
& { }^{E} \dot{\psi}=r
\end{aligned}
$$

このとき以下の座標変換により，風座標系 $\left(X_{w}, Y_{w}\right)$ を定義する.

$$
\begin{aligned}
& { }^{w} X(t)={ }^{E} X(t)-\int_{0}^{t} \tilde{W}_{x}(\tau) d \tau \\
& { }^{w} Y(t)={ }^{E} Y(t)
\end{aligned}
$$

これは, 飛行時の風に座標系をおいた空間 (平面) を考えたものであり, 風座標系における飛行船の運動学モデル は次のように表せる .

$$
\begin{aligned}
& { }^{w} \dot{X}=u \cos { }^{E} \psi \\
& { }^{w} \dot{Y}=u \sin ^{E} \psi \\
& { }^{E} \dot{\psi}=r
\end{aligned}
$$


本論文の定式化の利点は，定常的な風速・風向が観測可能な条件下で，風の定常成分 $\tilde{W}_{x}$ を座標系内に取り込み， これを外乱として扱わずに制御できることである．この風座標系内で制御系を設計することで, 式(1)では $W_{x}, W_{y}$ が外乱であるのに対し，式(4)では $\tilde{W}_{x}$ からのずれが外乱となり，風外乱の影響を小さくすることができる．従来 ではこれらの風速項をすべて外乱とみなし，以下のような設計モデルを用いて制御系設計を行い，制御系のロバ スト性により対処する方法をとってきた ${ }^{(2)(12)}$.

$$
\begin{aligned}
& { }^{E} \dot{X}=v_{g} \cos { }^{E} \psi \\
& { }^{E} \dot{Y}=v_{g} \sin { }^{E} \psi \\
& { }^{E} \dot{\psi}=r
\end{aligned}
$$

ここで, $v_{g}$ は地球座標系を基準とした飛行船の重心における対地速度である．また，屋内型飛行船の制御において も，風速情報を用いずに，制御則のロバスト性でこれらの变動に対処し，安定化制御を行う手法 ${ }^{(16)(17)}$ が提案され ている .しかし，屋内と屋外では外乱となる風速・風向の変動も大きく異なる上に，本論文で想定する風速 $5 \mathrm{~m} / \mathrm{s}$ 以上の強風時には，飛行船の運動に与える風の影響は非常に大きなものとなるため，制御系のロバスト性のみで は対処が難しく，これらの項を考慮したモデル化と制御系設計が重要となる．特に，強風時には飛行船が受ける 風の成分 ${ }^{(18)}$ として $\tilde{W}_{x}$ が占める割合が大きいことが実験的に明らかとなっており，これを外乱として扱わずに制 御することは非常に大きな意味を持つ．なお，これまでの飛行実験から得られた風速の代表的なデータを付録 $\mathrm{A}$ に示す．ただし，風座標系を設定するためにも，事前に風速 $W_{x}, W_{y}$ を推定する必要があるため，風速の推定を大 きく間違えた際には，制御結果も光の悪影響を受ける．このような場合には，改めて風座標系を設定しなおすこ とで対処する必要がある．

\section{$2 \cdot 2$ 風座標系内での Path following 制御}

Path following 制御 ${ }^{(19)}$ とは, 飛行船ロボットが飛行すべき参照経路を考えて, 実際の飛行船口ボットを光の経路上 に追従させる制御手法である。実ロボットを各時刻で指定された参照経路上の点に追従させる Tracking 制御 (20) (21) と違い, Path following 制御は, 進行速度を制御入力として扱わず, 旋回角速度のみを制御して目標経路に追従さ せる. Tracking 制御では，各時刻ごとに参照経路上の望ましい点に追従制御を行うため，各時刻ごとに生じる進 行方向 (式 (7) における $e_{1}$ 方向) の追従誤差が蓄積されていく可能性が高く，制御入力が非常に過大になるなど情 報収集を行う上で不都合が生じやすくなる．乥れに比べて，Path following 制御では，進行方向の追従制御と目標 経路への追従制御を独立に行うことで, 時間に依存して指定される参照経路上の望ましい点に遅れずについてい く必要がなくなり, 非ホロノミック系の Tracking 制御で起こりうる極端な前進や後退, また切り返し挙動を起こ しにくくすることができる .したがって , Path following 制御は本論文で想定しているようなあらかじめ設定した 経路上を，抜けなく飛行させるという制御目標を達成するのに適しており，情報収集に悪影響を与えにくくなる．

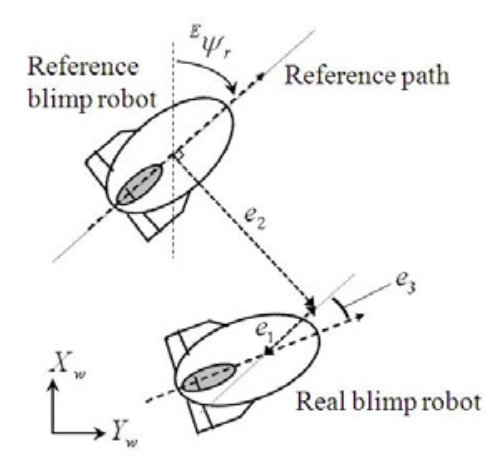

Fig. 5 Relationship between real and reference blimp robot in the wind coordinate

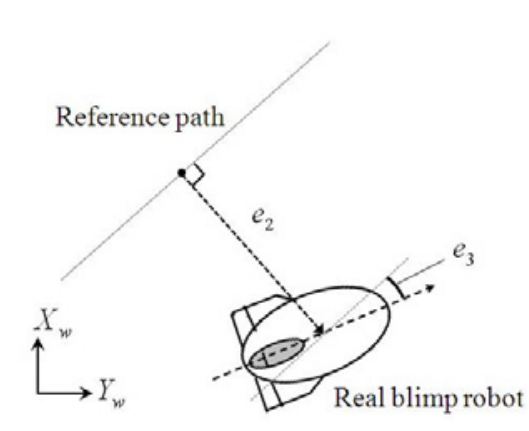

Fig. 6 Relationship between real blimp robot and reference path in the wind coordinate 
本論文では Tracking 制御の枠組を利用して，風座標系内において Path following 制御系を設計する. 图 5 のよう に風座標系内に参照経路を生成し，経路上を $\left[u_{r}, r_{r}\right]^{T}$ の速度で動く仮想的な参照飛行船口ボットを考える. 弚のと き，参照飛行船口ボットの運動学モデルは

$$
\begin{aligned}
& { }^{w} \dot{X}_{r}=u_{r} \cos { }^{E} \psi_{r} \\
& { }^{w} \dot{Y}_{r}=u_{r} \sin ^{E} \psi_{r} \\
& { }^{E} \dot{\psi}_{r}=r_{r}
\end{aligned}
$$

となり，参照ロボットから見た実ロボットとの相対位置誤差を次のように定義できる．

$$
\left[\begin{array}{l}
e_{1} \\
e_{2} \\
e_{3}
\end{array}\right]=\left[\begin{array}{ccc}
\cos ^{E} \psi_{r} & \sin { }^{E} \psi_{r} & 0 \\
-\sin { }^{E} \psi_{r} & \cos { }^{E} \psi_{r} & 0 \\
0 & 0 & 1
\end{array}\right]\left[\begin{array}{c}
{ }^{w} X-{ }^{w} X_{r} \\
{ }^{w} Y-{ }^{w} Y_{r} \\
{ }^{E} \psi-{ }^{E} \psi_{r}
\end{array}\right]
$$

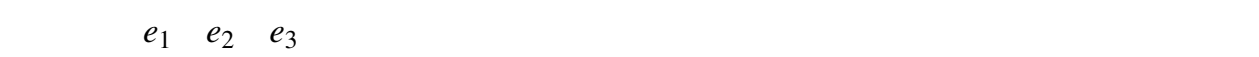

また，上式の時間に関する微分は次のようになる .

$$
\begin{aligned}
& \dot{e}_{1}=u \cos e_{3}-u_{r}+e_{2} r_{r} \\
& \dot{e}_{2}=u \sin e_{3}-e_{1} r_{r} \\
& \dot{e}_{3}=r-r_{r}
\end{aligned}
$$

Tracking 制御の枠組から Path following 制御の枠組に変更するために, 図 6 のように参照飛行船ロボットが常に 実際の飛行船ロボットの真横にあることを考える．つまり，式(7)，(8)において $e_{1}=\dot{e}_{1}=0$ となるように参照飛 行船ロボットの速度を

$$
u_{r}-e_{2} r_{r}=u \cos e_{3}
$$

と選ぶ . このとき，誤差方程式は次のように書き直すことができる .

$$
\begin{aligned}
& \dot{e}_{2}=u \sin e_{3} \\
& \dot{e}_{3}=r-r_{r}
\end{aligned}
$$

したがって，実際の飛行船ロボットと参照経路との左右方向およびヨー角の誤差を考えれば良いこととなり，前後 方向の速度制御を切り離すことができる. 参照経路からの左右方向の誤差 $e_{2}, \exists$ 一角方向の誤差 $e_{3}$ を 0 に収束さ せる望ましい飛行船のヨ一角速度 $r_{c}$ を以下のように考える。

式 (10) に対して, Lyapunov 関数候補を

$$
V=\frac{1}{2} K_{2} e_{2}^{2}+\frac{1}{2} K_{3} e_{3}^{2}
$$

とすると，弚の時間に関する微分は

$$
\begin{aligned}
\dot{V} & =K_{2} e_{2} \dot{e}_{2}+K_{3} e_{3} \dot{e}_{3} \\
& =K_{2} e_{2} u \sin e_{3}+K_{3} e_{3}\left(r-r_{r}\right)
\end{aligned}
$$

となる．ここで, $K_{2}, K_{3}$ は任意の正定数である.

飛行船に与える望ましいヨ一角速度 $r_{c}$ を，ある正定数 $K_{4}$ を用いて

$$
r_{c}=r_{r}-K_{4} e_{3}-\frac{K_{2} e_{2} u \sin e_{3}}{K_{3} e_{3}}
$$

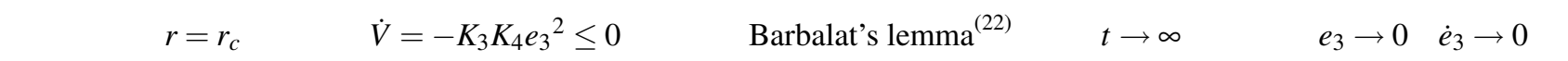
なる、また，

$$
\begin{aligned}
\dot{e}_{3} & =r-r_{r} \\
& =-K_{4} e_{3}-\frac{K_{2} e_{2} u \sin e_{3}}{K_{3} e_{3}}
\end{aligned}
$$


であり，

$$
\lim _{e_{3} \rightarrow 0} \frac{\sin e_{3}}{e_{3}} \rightarrow 1
$$

であるので, $u$ が任意の微小な正数値より大きくかつ一樣連続であるとき,$t \rightarrow \infty て ゙ e_{2} \rightarrow 0$ となり, $e_{2}, e_{3} を 0$ に 収束させることができる．以上により，飛行船の対気速度 $u$ を適切に制御し，飛行船のヨ一角速度 $r$ が $r_{c}$ となれ ば，飛行船は対気速度 $u$ で参照経路に追従する。

本論文では以下の速度フィードバック制御により，実ヨ一角速度 $r$ が望ましいヨー角速度 $r_{c}$ になるように，飛 行船の方向舵角 $\delta_{r}$ を制御する.

$$
\delta_{r}=K_{p r}\left(r-r_{c}\right)+K_{i r} \int\left(r-r_{c}\right) d t+K_{d r} \frac{d}{d t}\left(r-r_{c}\right)
$$

ここで， $\delta_{r}$ は飛行船を船尾から見て左側を正方向とし， $K_{p r}, K_{i r}, K_{d r}$ は任意の正定数である.

\section{$2 \cdot 3$ 経路再生成}

自律飛行により詳細な情報収集を効率良く行うためには，目標経路への高い追従性能が求められる，弚のため， 制御ゲインを大きな值に設定する必要があるが, 飛行船は風の影響を受けやすいため, 位置制御に関するゲイン を大きくしすぎると，強風時に大きなヨ一角の変化や目標経路付近での蛇行などの不適切な挙動を示すことが考 えられる，一方で，姿勢の安定化や蛇行の防止を重視して位置制御に関するゲインを小さくすると，横方向から の突風を受けた際に目標経路に対する偏差が大きくなったり，最悪発散してしまうことが考えられる．

そこで本論文では, 目標経路からの横偏差の大きさに応じて, 飛行船が追従すべき参照経路を目標経路に対し て再生成することで, 飛行船が横風外乱を受けて目標経路を逸脱した場合にも，制御則のゲインを変えずに滑らか かつ迅速に経路復帰可能な方法を提案する . 図 7 のよう目標経路からの横偏差の大きさに応じて, 風座標系内 でいくつかの領域を設定する . 経路への迅速な復帰のために，各領域ごとに望ましいヨー角 ${ }^{E} \tilde{\psi}_{r i}$ を目標経路に向

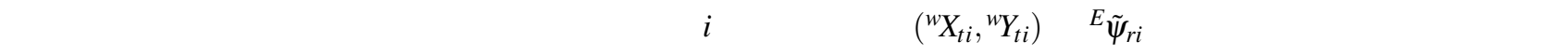
領域 0 の外では ${ }^{E} \tilde{\psi}_{r i}$ は非零の一定值で与え, 誤差が大きい場合により速く経路復帰できるように，経路からより 遠くの領域になるほど ${ }^{E} \tilde{\psi}_{r i} \mid$ を大きな值に設定する . 一方 , 領域 0 内では

$$
{ }^{E} \tilde{\psi}_{r 0}(t)={ }^{E} \tilde{\psi}_{r 1} \frac{{ }^{w} Y_{r 0}(t)}{\Delta^{w} Y}
$$

により ${ }^{E} \tilde{\psi}_{r 0}$ を決定し，目標経路に滑らかに追従しやすい值とする．ここで， $\Delta^{w} Y$ は飛行船が領域 0 に入った位置 から目標経路までの距離， ${ }^{W} Y_{r 0}(t)$ は領域 0 内で生成された参照経路の各時刻における $Y_{w}$ 軸の座標値である.

以上のように決定された ${ }^{E} \tilde{\psi}_{r i}$ を基に, 各領域ごとに参照経路を生成する.しかし, 図 7 に示すように飛行船が ある領域に入った際に, 弚の領域 $i$ の ${ }^{E} \tilde{\psi}_{r i}$ の方向を向いているとは限らない. 兴のため, 図 7 の橙色の曲線のよ うに, 弚の領域 $i$ につた際の初期ヨ一角 ${ }^{E} \psi_{t i}$ から望ましいヨー角 ${ }^{E} \tilde{\psi}_{r i}$ に滑らかに変化するような参照経路を生 成することで，領域が切り替わった瞬間に制御入力が飽和しないようにする．具体的には，以下のような ${ }^{E} \psi_{r i}$ を 用いて参照経路を生成する．

$$
{ }^{E} \boldsymbol{\psi}_{r i}(t)={ }^{E} \tilde{\psi}_{r i}+\left({ }^{E} \boldsymbol{\psi}_{t i}-{ }^{E} \tilde{\psi}_{r i}\right) e^{-\frac{1}{T} t}
$$

ここで, $T$ は時定数,$e$ は自然対数である. 各領域における参照経路は以下のように決定される .

$$
\begin{aligned}
& { }^{w} X_{r i}(t)=\int_{0}^{t}\left(u_{r}(\tau) \cos { }^{E} \psi_{r i}(\tau)\right) d \tau+{ }^{w} X_{t i} \\
& { }^{w} Y_{r i}(t)=\int_{0}^{t}\left(u_{r}(\tau) \sin { }^{E} \psi_{r i}(\tau)\right) d \tau+{ }^{w} Y_{t i}
\end{aligned}
$$

ここで,$\left({ }^{w} X_{t i},{ }^{w} Y_{t i}\right)$ は弚の領域 $i$ につた際の位置である .

以上により，飛行船が横風外乱を受けて経路から誤差を持った場合にも，各領域で再生成された参照経路に追従 させることで, 各領域ごとに $e_{2}, e_{3}$ を小さな值にでき, 位置制御に関するゲインを変えずに滑らかかつ迅速に経 路復帰することが可能となる、なお，本論文では具体的に表 1 のように領域を分割し，飛行シミュレーションお よび実験を行った . 


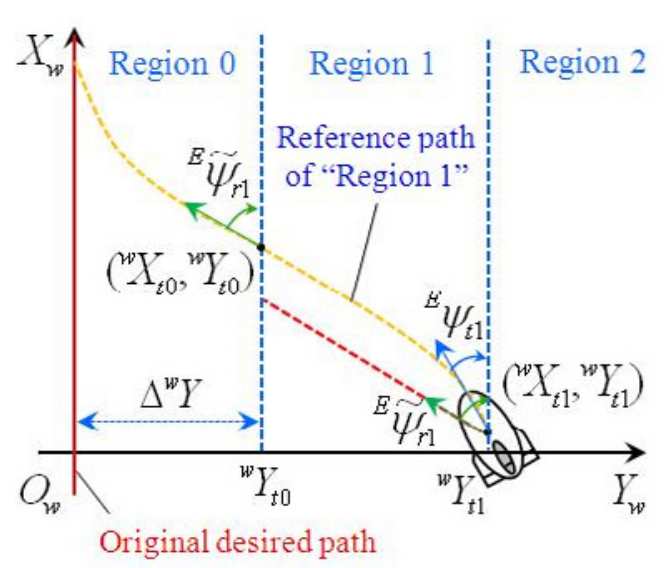

Fig. 7 Path regenaration in the wind coordinate

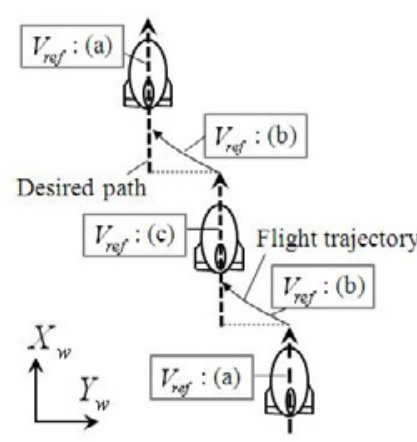

Wind coordinate

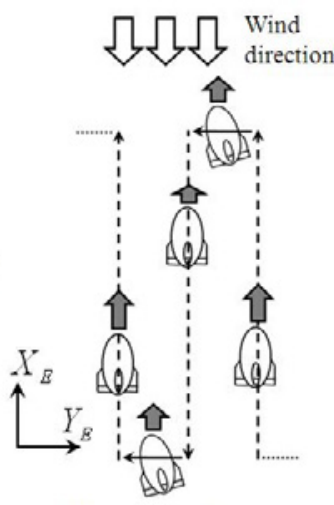

World coordinate

Fig. 8 Path following flight for information gathering under strong wind by using proposed method

Table 1 Parameters of path regeneration

\begin{tabular}{|c|c|c|}
\hline \multicolumn{3}{|c|}{$\left({ }^{w} Y-{ }^{w} Y_{r}\right)<0$} \\
\hline Region -2 & $-10<\left({ }^{w} Y-{ }^{w} Y_{r}\right)$ & ${ }^{E} \tilde{\boldsymbol{\psi}}_{r(-2)}=0.175[\mathrm{rad}]$ \\
\hline Region -1 & $-10 \leq\left({ }^{w} Y-{ }^{w} Y_{r}\right)<-4$ & ${ }^{E} \tilde{\boldsymbol{\psi}}_{r(-1)}=0.087[\mathrm{rad}]$ \\
\hline Region 0 & $-4 \leq\left({ }^{w} Y-{ }^{w} Y_{r}\right)<0$ & ${ }^{E} \tilde{\psi}_{r 0}(t)=\frac{0.087}{4}{ }^{w} Y_{r 0}(t)[\mathrm{rad}]$ \\
\hline \multicolumn{3}{|c|}{$0 \leq\left({ }^{w} Y-{ }^{w} Y_{r}\right)$} \\
\hline Region 0 & $0 \leq\left({ }^{w} Y-{ }^{w} Y_{r}\right)<4$ & ${ }^{E} \tilde{\psi}_{r 0}(t)=-\frac{0.087}{4}{ }^{w} Y_{r 0}(t)[\mathrm{rad}]$ \\
\hline Region 1 & $4 \leq\left({ }^{w} Y-{ }^{w} Y_{r}\right)<10$ & ${ }^{E} \tilde{\psi}_{r 1}=-0.087[\mathrm{rad}]$ \\
\hline Region 2 & $10 \leq\left({ }^{w} Y-{ }^{w} Y_{r}\right)$ & ${ }^{E} \tilde{\psi}_{r 2}=-0.175[\mathrm{rad}]$ \\
\hline
\end{tabular}

\section{$2 \cdot 4$ 速度制御}

本節では，経路追従時の飛行船の進行方向の速度制御について述べる．Path following 制御の枠組により，飛行 船の進行速度は独立に制御可能であるため, 飛行船の推進器のスロットル入力 $\delta_{t}$ を以下のように与え, 進行方向 の速度制御を行う。

$$
\delta_{t}=-K_{p t}\left(u-\frac{V_{r e f}+\tilde{W}_{x}}{\cos ^{E} \psi_{r}}\right)
$$

ここで, $K_{p t}$ は任意の正定数， $V_{r e f}$ は飛行船進行方向の目標対地速度である.

目標速度 $V_{r e f}$ を定常風速 $\tilde{W}_{x}$ に応じて以下のように与えることで, 経路追従時の飛行形態を切替える。

(a) $V_{r e f}>0:$ 目標経路に沿って前進飛行 $\left(u>\tilde{W}_{x}\right)$

(b) $V_{r e f}=0:$ 目標経路上で滞空 $\left(u=\tilde{W}_{x}\right)$

(c) $0>V_{\text {ref }}>-\tilde{W}_{x}:$ 目標経路に沿って後退飛行 $\left(\tilde{W}_{x}>u>0\right)$

風座標系において Path following 制御を行うとともに, 図 8(左)のように目標速度 $V_{r e f}$ を与えることで, 風座標内 では常に前進しながら経路追従を行うが, 地上から見ると定常風下で図 8(右)のように前進, 後退を繰り返しなが ら飛行することとなる.さらに，前節で示した経路再生成に合わせて，領域 0 の外で $V_{r e f}$ を (b) として与えること で, 横風外乱を受けて飛行船が経路を逸脱した場合に，図 9 のように経路に対して真横移動しながら経路復帰す ることとなり，進行方向に対しても計測による情報の抜けを防ぐことが期待できる．なお，飛行時の風速が $5 \mathrm{~m} / \mathrm{s}$ 未満の場合に上記の (c) を実現するためには, 風座標系内でも後退が必要となるが, 風速 $5 \mathrm{~m} / \mathrm{s}$ 未満の状況下にお いては, 図 1 の飛行経路に対して従来の制御手法を用いることで実用上十分な精度で飛行可能であるため，本論 文では風速 $5 \mathrm{~m} / \mathrm{s}$ 未満の状況下は想定しない。 


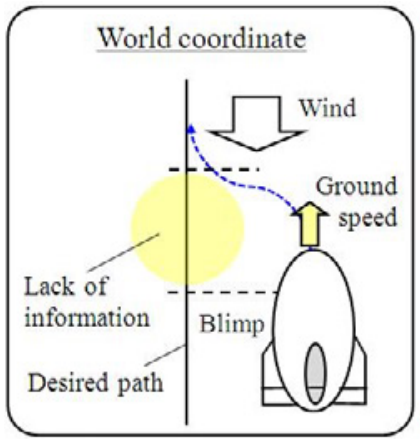

Path following based on ground

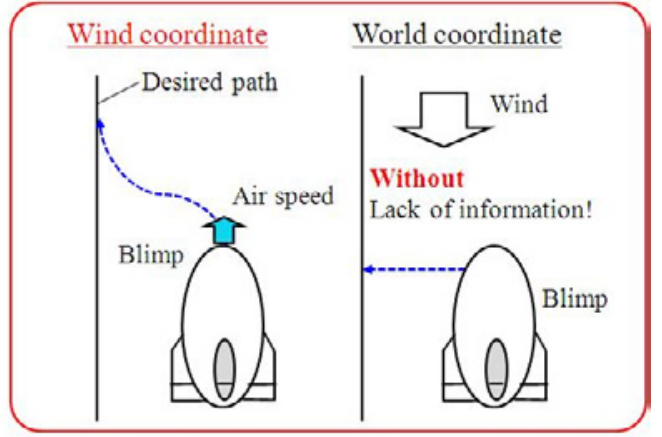

Path following in the air

Fig. 9 Performance comparison between path following based on ground and the one in the air

\section{3. 飛行制 御 実験}

本章では，前章までに提案した手法を用いて飛行制御実験を行った結果について述べる．

\section{$3 \cdot 1$ 屋外型飛行船ロボット}

飛行制御実験で使用した本研究グループの飛行船ロボットを図 10 に示す. 全長 $12 \mathrm{~m}$ 級のラジコン型軟式飛行船 を改造したものであり，機体の仕樣は表 2 の通りである . なお，表 2 のペイロードはカメラやレーザといった計 測機器，バッテリや燃料を除いた值であり，気温や気圧の変化を大きく受けるものである .

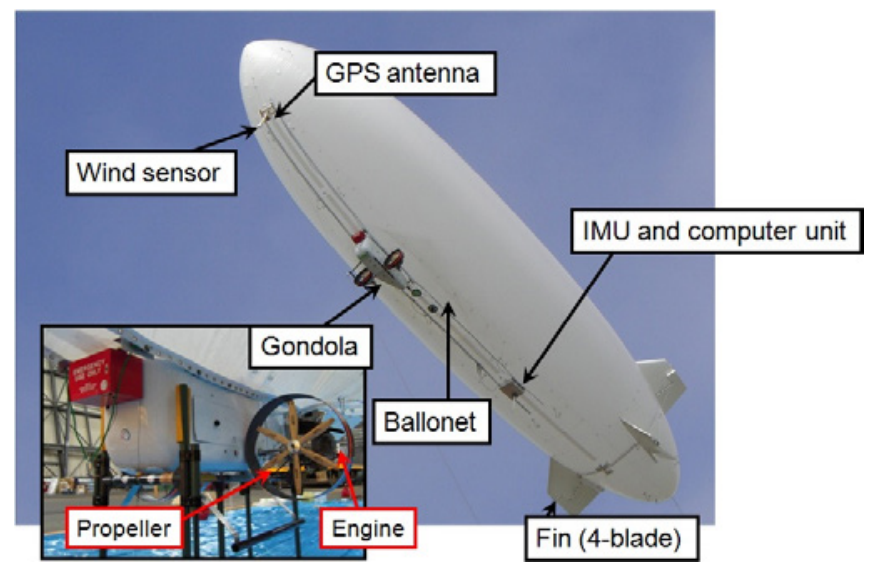

Fig. 10 Our outdoor blimp robots

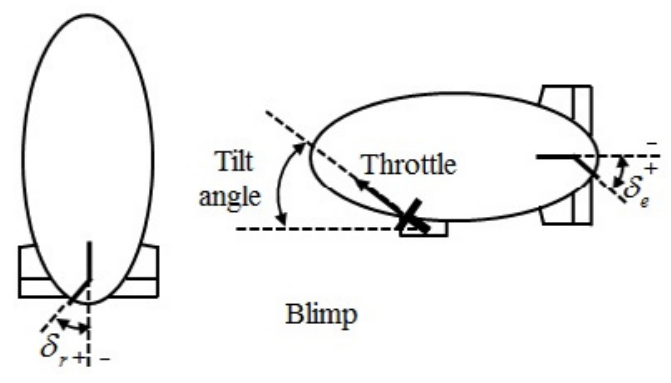

Fig. 11 Actual control inputs of the blimp

操舵には，船体後部にX 型に配置した舵面のついた安定尾翼を用いる . 尾翼舵面はサーボモータにより，最大 で45[deg] まで可動することができ, 图 11 のように方向舵角入力 $\delta_{r}$ と昇降舵角入力 $\delta_{e}$ を飛行船に与え, 光れ光 れの入力を複合した方向に可動させることで飛行時の姿勢を制御する . また , ゴンドラの左右に一台ずつ, $62 \mathrm{cc}$ のエンジンと光れに直結する 6 肢プロペラで構成された推進器を動力源とする . 左右の推進器は連動してチルト させることが可能であり，図 11 のようにエンジンのスロットル量およびチルト角を制御することで , 飛行時の進 行速度を制御する.なお，推進器は推進軸を基準として最大で $\pm 180[\mathrm{deg}]$ のチルト回転が可能である . また制御 に用いるセンサとしては，機体前部に慣性座標系における飛行船の位置と速度を計測するための GPS アンテナお よび対気速度を計測するための超音波風速計，機体下部に飛行船の姿勢および姿勢角速度を計測するための高精 度 IMU(Inertial Measurement Unit) を搭載している。 
Table 2 Specification of our blimp robot

\begin{tabular}{|c|c|}
\hline Length & $12.2[\mathrm{~m}]$ \\
\hline Maxaimum diameter (Envelope) & $3.05[\mathrm{~m}]$ \\
\hline Volume (Envelope) & $59.4\left[\mathrm{~m}^{3}\right]$ \\
\hline Payload & $8.0[\mathrm{~kg}]$ \\
\hline Maximum speed & $15.0[\mathrm{~m} / \mathrm{s}]$ \\
\hline
\end{tabular}

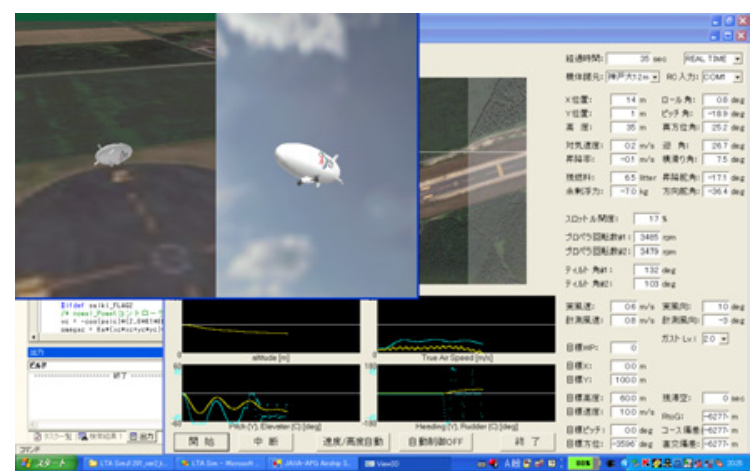

Fig. 12 LTA unmanned vehicle simulator

\section{$3 \cdot 2$ 飛行シミュレーション}

実機による飛行制御実験に先立ち，数值シミュレーションにより本提案手法の有効性の検証を行った . 飛行シ ミュレーションには, JAXA 無人機・未来型航空機チームが開発した図 12 の LTA 無人機シミュレータ ${ }^{(23)}$ を用い た . 本シミュレータには, 風洞試験および実機によるパラメータ同定試験から得られた空気力モデル ${ }^{(24)(25) な と ゙ か ゙ ~}$ 実装されており，実際の実験機の挙動に近いシミュレーションを行うことが可能である . 飛行シミュレーション の代表例として, 目標経路から大きな初期誤差を持つ場合の直線経路への追従制御 (シミュレーション 1), 強風下 での情報収集を想定して，複数の直線経路への追従を繰り返す制御 (シミュレーション 2)を示す . シミュレーショ ン内容の詳細は以下の通りである .

シミュレーション $1:$ 定常風 $9 \mathrm{~m} / \mathrm{s}$ において, 風上に船首を向けた滞空状態から制御を開始する.目標となる直

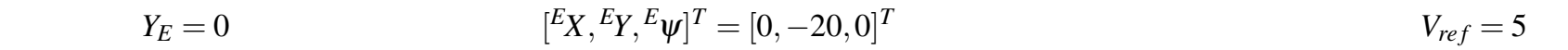
経路に追従させる．

シミュレーション $2:$ 定常風 $10 \mathrm{~m} / \mathrm{s}$ において, 風上に船首を向けた滞空状態から制御を開始する . 飛行船の初期 状態を $\left[{ }^{E} X,{ }^{E} Y,{ }^{E} \psi\right]^{T}=[0,-5,0]^{T}$ に設定し，初期高度を維持しながら， $V_{r e f}=5$ で第一の目標経路 $Y_{E}=0$ に追従さ
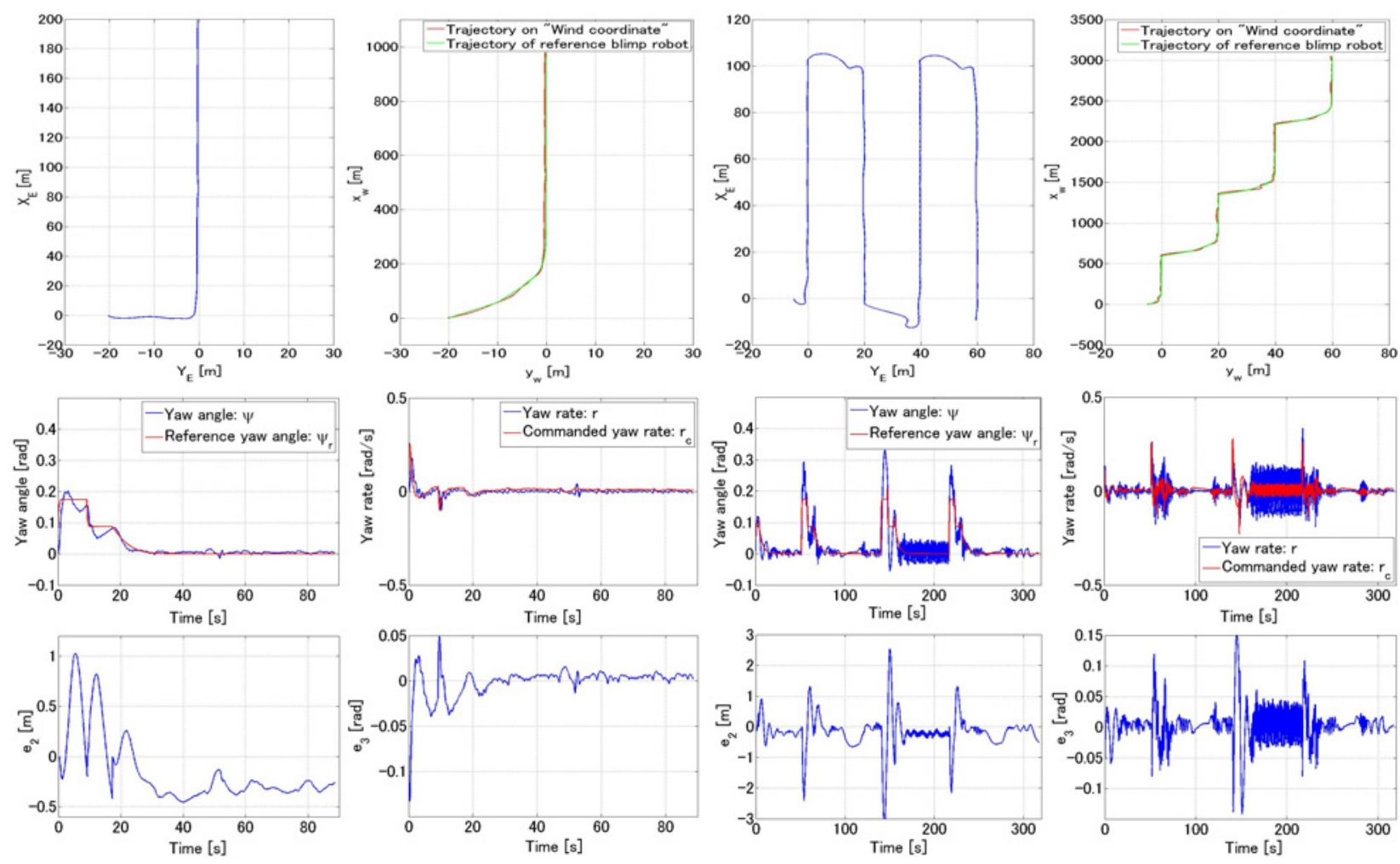

Fig. 13 Simulation results: Case 1

Fig. 14 Simulation results: Case 2 
せる . 飛行船が ${ }^{E} X=100$ の位置に到達すると同時に，第二の目標経路を $Y_{E}=20$ に再設定し， $V_{r e f}=-2$ でこの 経路に追従させる.再び飛行船が ${ }^{E} X=0$ に到達すると同時に，第三の目標経路を $Y_{E}=40$ に再設定し， $V_{r e f}=5$ で追従させる．これを繰り返すことで，実際の情報収集を想定した経路追従飛行を行う．なお，両シミュレーショ ンとも経路追従時の飛行船の位置が領域 0 外の場合には， $V_{r e f}=0$ で進行速度を制御し，目標経路に対して真横移 動させるものとした .

シミュレーション 1 の結果を図 13 に示す.この結果は水平面内における制御結果を示しており，左上のグラフ は地球座標系内の飛行船の実際の飛行軌跡, 右上は風座標系内の飛行軌跡 (赤線) と経路再生成による参照経路 (緑線) を表している．風座標系内において再生成された参照経路に正確に追従することで, 不適切な挙動を示さ ず滑らかに目標経路に追従している．また速度制御も良好に行われており，目標経路に真横に移動できているこ とが確認できる.目標経路に対する左右方向の誤差も，直線経路部分で最大 $0.43[\mathrm{~m}]$ と目標誤差内に収まってお り，良好な結果となっている.さらにシミュレーション 2 の結果を図 14 に示す.シミュレーション 2 においても， 直線経路部分において経路からの横方向の誤差が約 $0.5[\mathrm{~m}]$ 以内に収まっていることが確認できる．この結果から， 本提案手法により, 定常風下において前進, 後退を繰り返し行っても, 直線経路部分において目標誤差内に制御で きており，強風下での情報収集を行うのに十分な基本性能が確認できた .

\section{$3 \cdot 3$ 飛行制御実験}

実環境における本提案手法の有効性を検証するために，以下の飛行制御実験を行った．

- 2011 年 10 月 3 日 14 日 JAXA 大樹航空宇宙実験場 (北海道)

- 2012 年 1 月 17 日 27 日 IHI 七ツ島場外離着陸場 (鹿児島県)

手動操縦により，実験機を事前に風上の方向に向けた状態から，自動制御に切替えて経路追従飛行制御を行った． 制御開始時の方向に $X_{E}$ 軸を設定し, 弚の軸上の風速 $W_{x}$ の推定値の $10[\mathrm{sec}]$ 間の移動平均を $\tilde{W}_{x}$ として, 実験を 行った .まず，以下のような実験を行った結果について述べる .
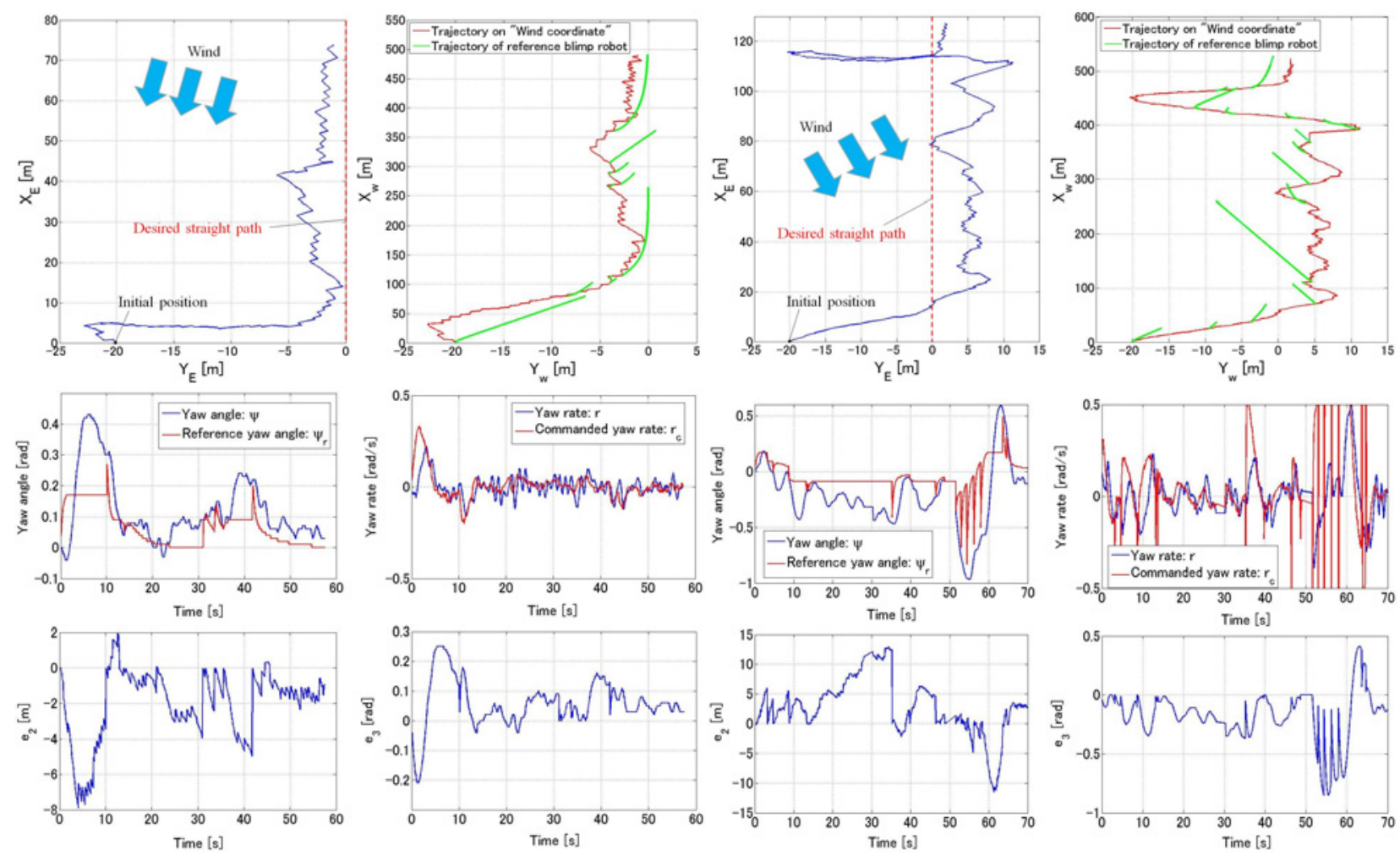

Fig. 15 Experimental results: Case 1

Fig. 16 Experimental results: Case 2 

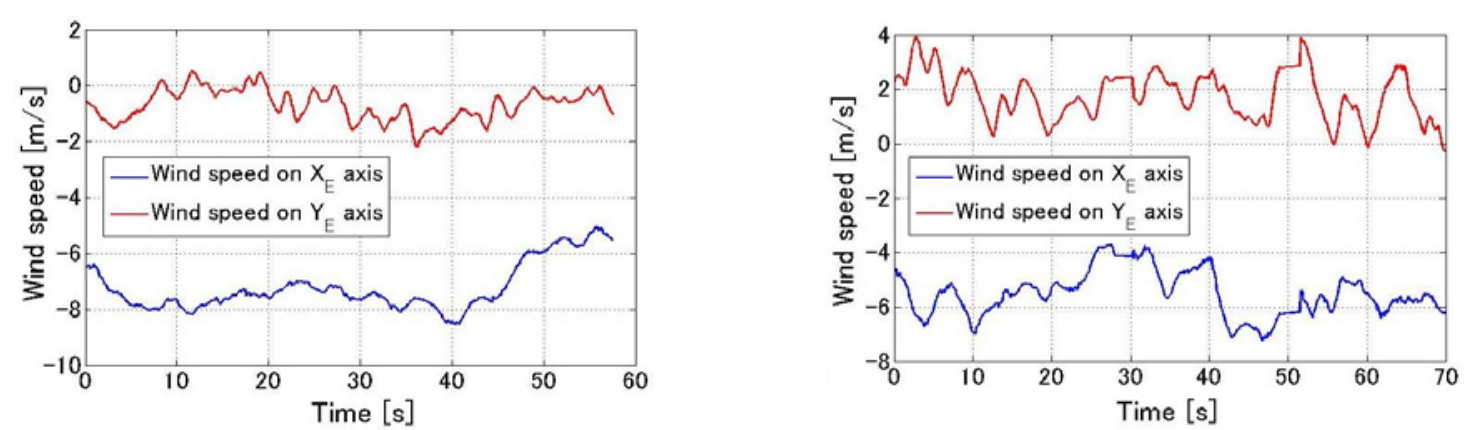

Fig. 17 Estimated values of wind speed (left: Case 1, right: Case 2)

実験 $1:$ 上空風速約 $8 \mathrm{~m} / \mathrm{s}$ で, 風向変動が稂やかな状況下で大きな初期誤差を持たせた場合の直線経路追従制御 を行う．目標となる直線経路を $Y_{E}=0$, 飛行船の初期状態を $\left[{ }^{E} X,{ }^{E} Y,{ }^{E} \psi\right]^{T}=[0,-20,0]^{T}$ に設定し，初期高度を維 持しながら， $V_{r e f}=5$ で経路に追従させる．

実験 $2:$ 上空風速約 $7 \mathrm{~m} / \mathrm{s}$ で, 風向変動が存在する状況下で大きな初期誤差を持たせた場合の直線経路追従制御 を行う.実験 1 と同樣の初期条件，制御仕樣により，初期高度を維持しながら目標経路に追従させる．また実験 1 , 2 ともシミュレーションと同じく，経路追従時の飛行船の位置か領域 0 外の場合には， $V_{r e f}=0$ で進行速度を制御 し，目標経路に対して真横移動させるものとした .

実験 1 の結果を図 15 に，実験 2 の結果を図 16 に示す .これらのグラフもシミュレーション結果と同じく，水平 面内の制御結果を示したものである.なお，実験結果において緑線で示した参照経路や参照方位角 $\psi_{r}$ が幾つかの 地点で不連続となっているが，これは 2.3 節の経路再生成によるものである.また制御時の風速の推定値を，図 17 (左: 実験 1 , 右: 実験 2 ) に示す.これは，飛行船に搭載した風速センサから得られる対気速度と GPSにより得ら れる対地速度から風速を推算したものであり，この結果を用いて $\tilde{W}_{x}$ を求め，風座標系内で制御を行った．実験 1 の結果から，シミュレーションと同樣に風座標系内で再生成した参照経路に追従することで，地上から見ると滑ら かに目標経路に追従していることがわかる．また速度制御も良好に行われており，実環境においても目標経路に対 して真横方向に移動できている.実験 2 においては, 図 17(右)の赤線が示すように, 実際の風向が制御開始時に 座標系を設定した風上の方向と異なっていたと考えられる．弚のため，この座標系設定時のずれにより全体的に 経路に対する左右方向の誤差が大きくなってしまっている．しかし，このような場合にも経路再生成を行った効 果はでており，誤差が大きくなり始めた初期段階で経路に復帰しようしていることが確認できる. 特に ${ }^{E} X=115$ 付近においては, 突風の影響を受けて目標経路を大きく逸脱しているが, 経路再生成と速度制御がうまく機能し， 情報収集を阻害しない有効な経路復帰が行えていることがわかる．以上のように，本提案手法の強風時の有効性 は確認できたが，目標経路に対する誤差が $1 \mathrm{~m}$ 以上となっており，さらなる追従性能の改善が必要である．また， 実験 2 のような座標系設定時の風向のずれや, 飛行時の風向変動による定常的な横風外乱の発生は, 実際の運用 時にも十分に考えられるため，ある程度の横風外乱に対する性能向上も必要である．

光のため, 飛行船に与える望ましいヨ一角速度 $r_{c}$ に, 目標経路に対する左右誤差 $e_{2}$ を小さくする積分項を以下 のように加えることを考える .

$$
r_{c}(t)=r_{r}(t)-K_{4} e_{3}(t)-\frac{K_{2} e_{2}(t) u(t) \sin e_{3}(t)}{K_{3} e_{3}(t)}-K_{5} \int_{0}^{t} e_{2}(\tau) d \tau
$$

ここで， $K_{5}$ は $K_{2}$ に対して十分に小さな任意の正数とする . 飛行船の実ヨ一角速度 $r$ を上式の $r_{c}$ に追従させるこ とで, 横風外乱により発生する定常偏差の低減を行い, 飛行船の目標経路に対する誤差を $1 \mathrm{~m}$ 以内に抑えることを 目指す .この項を加えたことによる有効性を検証するために，以下の実験を行った .

実験 $3:$ 上空風速約 $8 \mathrm{~m} / \mathrm{s}$, 初期誤差なし (初期状態 $\left[{ }^{E} X,{ }^{E} Y,{ }^{E} \psi\right]^{T}=[0,0,0]^{T}$ ) の条件下で $V_{r e f}=-2$ で後退しなが ら，目標経路 $Y_{E}=0$ に追従させる.さらに飛行船に与える望ましいヨー角速度 $r_{c}$ を式 (20) とすることで, 目標経 路への追従性能の向上を目指す．

実験 3 における水平面内の制御結果を図 18 に示す.この結果から，図の右下に制御時の風速の推定値，弚の左 隣に $X_{E}$ 軸方向の飛行船の対地速度と目標速度 $V_{r e f}$ の時間に関するグラフを追加した . 実験結果から，制御開始時 に飛行船が前進速度を持っていたため, 減速させる際に目標経路から誤差が生じているが, 光の後良好に制御さ 
れており， ${ }^{E} X=-10$ 以降では誤差を $1 \mathrm{~m}$ 以内に抑えることができている.

最後に実験 3 と同じ制御則により，シミュレーション 2 のような飛行経路で飛行制御を行った結果について述

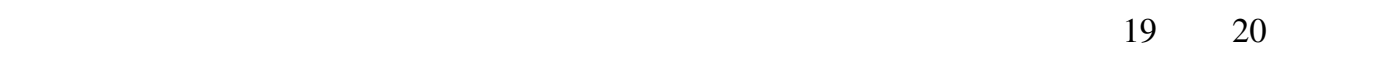

実験 $4:$ 上空風速約 $5 \mathrm{~m} / \mathrm{s}$, 初期誤差なしの条件下で, 初期高度を保ちながら， $V_{r e f}=5$ で第一の目標経路 $Y_{E}=0$ に追従させる.飛行船の位置が ${ }^{E} X=60$ に到達すると同時に，第二の目標経路を $Y_{E}=40$ に再設定する. 飛行船の 位置が第二の経路に対する領域 0 内になるまで $V_{r e f}=0$ で真横移動させ , 領域 0 内に到達後, $V_{r e f}=-2$ で後退し ながら追従飛行させる．

実験 $5:$ 上空風速約 $10 \mathrm{~m} / \mathrm{s}$ で風向変動がかなり激しい状況下で, 実験 4 と同樣の制御を行う. 実験 5 では飛行船 が第二の目標経路 $Y_{E}=40$ に沿って後退し， ${ }^{E} X=0$ に到達後，第三の目標経路を再び第一の目標経路に設定し，長 方形型の経路に対して繰り返し飛行させた．

弚れ帒れの結果とも，目標経路に対して良好に制御されており，目標経路を逸脱してしまった場合にも情報の 抜けを防ぐような飛行経路で復帰できている．特に実験 5 の結果を見ると，座標系設定時の風向が異なっていた 上に, 風向変動による大きな横風外乱を受けているにもかかわらず, 良好に経路追従が行えており, 式 (20)の積 分項の導入の効果が確認できる．また，このケースを行った際には，熟練したパイロットでも安定した飛行が相 当に難しく，ほんの少しの修正舵の遅れでかなり風に流されていたため，本論文における風座標系での制御系設 計と経路再生成が実環境において非常に有用であることを示すことができた . ただし，積分項を追加することで， 安定性の証明が出来なくなるため, 積分項の安定性に与える影響について，今後検討が必要である．

\section{4.お りり に}

本論文では，飛行船を用いて広範な災害情報を自動収集する際に，強風時に有効となる経路追従制御法として， 制御時の最大の問題である風をすべて外乱として扱うのではなく，風に座標系をおいた空間内で制御系を設計す ることにより，従来の手法よりも風の影響を小さく扱うことができる飛行船に特有な方法を提案した．さらに自 律飛行により情報収集を行うために有効となる経路再生成と速度制御を導入し, 飛行シミュレーションおよび実 機を用いた飛行制御実験を行い，実環境での非常に高い有用性を示した．

謝辞

本研究は，(財) セコム科学技術振興財団の助成により実施した．ここに謝意を表します．
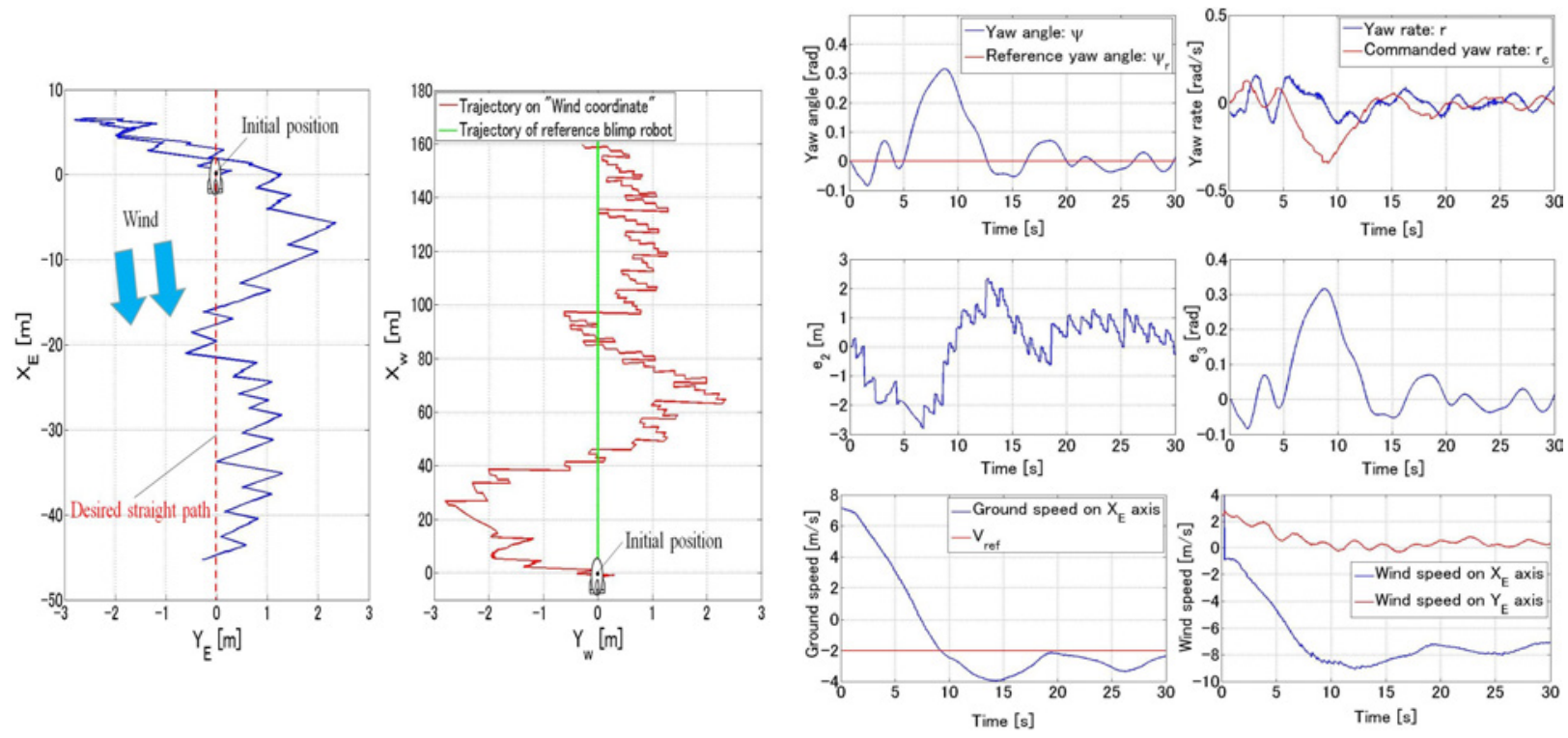

Fig. 18 Experimental results: Case 3 

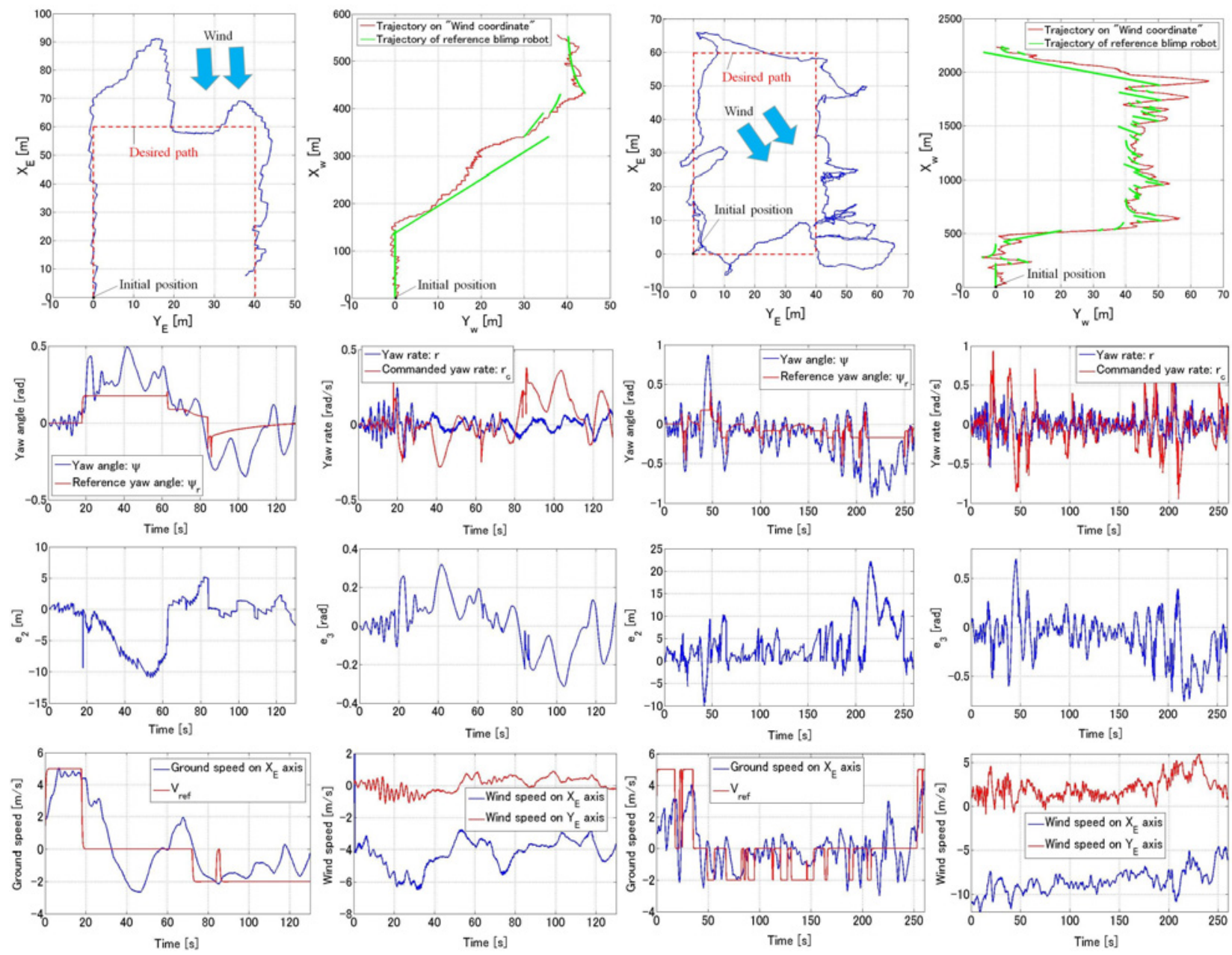

Fig. 19 Experimental results: Case 4
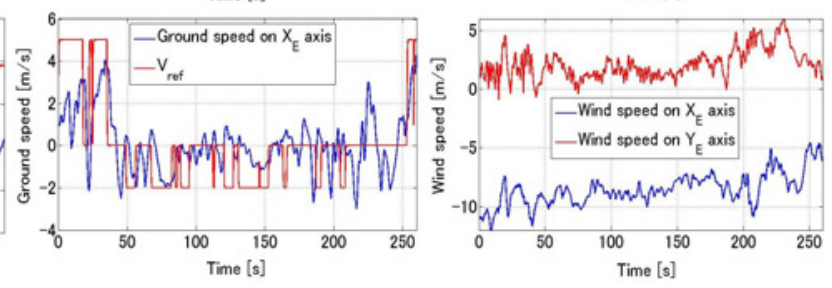

Fig. 20 Experimental results: Case 5

\section{付録 $\mathbf{A}$ 飛行実験から 得られた代表的な風データ}

以下に，風速の異なる日に飛行船に搭載した風速計によって得られた代表的な風のデータを示す．実験データ を見ると，飛行船が受ける風速が大きくなっても変動成分はさほど変わっていないことが確認できる．弚のため， 数十分程度のオーダーでは風速の変動は乥れほど大きなものではないと考えられ，風座標系を用いて制御するこ とで, 強風時の風外乱の影響を, 従来法で弱風時に受ける外乱程度に抑えることができることが期待できる．
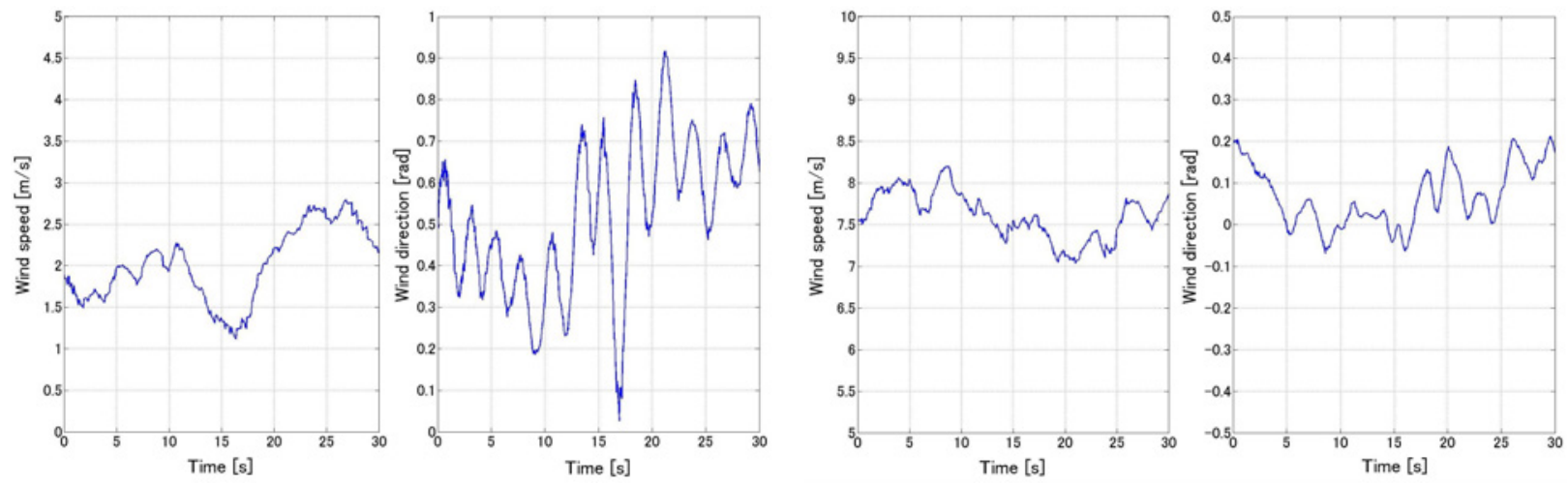

Fig. 21 Wind data A

Fig. 22 Wind data B 

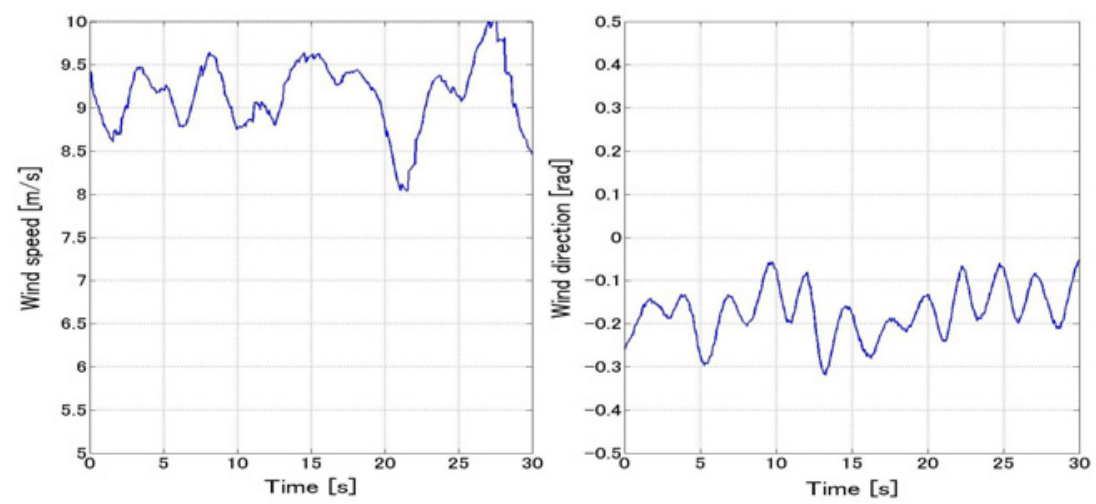

Fig. 23 Wind data C

付録 B 従来の制御手法との比較シミュレーション

以下に本論文で提案する風座標系を用いた制御手法と，従来の風座標系を用いない制御手法を弚れぞれ用いて 飛行シミュレーションを行った結果を比較し，本提案手法の有効性を示す. 飛行シミュレーションには, 図 12 に 示した LTA 無人機シミュレータを用いた 。

定常風 $8 \mathrm{~m} / \mathrm{s}$ において，風上に船首を向けた滞空状態から弚れ光れ制御を開始する.目標となる直線経路を $Y_{E}=0$ に設定し，飛行船の初期状態を $\left[{ }^{E} X,{ }^{E} Y,{ }^{E} \psi\right]^{T}=[0,30,0]^{T}$ に設定し，初期高度を維持しながら目標経路に追従させ

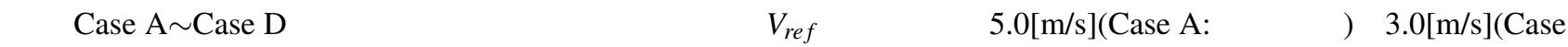
B: 低速前進), $1.0[\mathrm{~m} / \mathrm{s}]$ (Case C: 微速前進), $0.0[\mathrm{~m} / \mathrm{s}]$ (Case D: このケースでは真横移動)に設定して各目標速度ごと

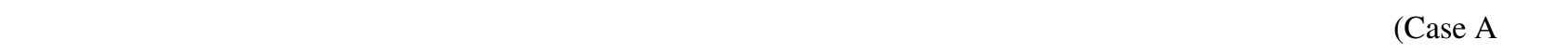
ける収束速度が提案手法に近くなるように制御ゲインを調整したもの), 緑線が提案手法と同樣の制御ゲインを用 いて従来手法で制御を行った結果を示す．なお，比較対象である従来法では 2.3 節の経路再生成は導入できないた め，本シミュレーションには経路再生成は用いていない，各シミュレーション結果から，提案手法を用いる方が 目標経路への収束速度がはやく，良好な結果となっているのがわかる.さらに，提案手法では飛行船の前進速度 が変わっても経路への収束性がほとんど同じなのに対して, 従来手法の方は前進速度が小さくなるにつれて収束 性が悪くなっており，前進速度に応じてさらなるゲイン調整が必要である．また，従来手法では Case D に示すよ うに真横への移動がほとんど不可能なのに対して，提案手法では飛行船が受ける風速を利用して，图のように巧 みに移動できていることが確認できる . 目標経路からの横方向誤差 $e_{2}$ に関する定常偏差についても表 3 に示すよ うに各手法に差が出ており，本提案手法は，強風下での経路追従制御において有効な結果となっている．さらに， 従来法では風速 $5 \mathrm{~m} / \mathrm{s}$ 以上の状況下では地球座標系において飛行船を後退させることが不可能 (従来法で後退させ るためには飛行船に与える望ましい対地速度が負になるため, 望ましいヨー角速度 $r_{c}$ も前進のときと符号が逆向 きになる .しかし，風速が $5 \mathrm{~m} / \mathrm{s}$ 以上の場合には実際の対気速度は正となっているため, 想定しているのと逆方向 に方向舵が効いてしまうためである)であり，弚のような比較は行えない．

Table 3 Steady-state deviation of $e_{2}$ in simulations

\begin{tabular}{|l|c|c|c|}
\hline & Proposed method: red line & Normal method 1: blue line & Normal method 2: green line \\
\hline Case A & $-0.21[\mathrm{~m}]$ & $-0.38[\mathrm{~m}]$ & $-0.57[\mathrm{~m}]$ \\
\hline Case B & $-0.34[\mathrm{~m}]$ & $-0.85[\mathrm{~m}]$ & $-1.13[\mathrm{~m}]$ \\
\hline Case C & $-0.62[\mathrm{~m}]$ & $-3.22[\mathrm{~m}]$ & $3.15[\mathrm{~m}]$ \\
\hline Case D & $-0.72[\mathrm{~m}]$ & - & - \\
\hline
\end{tabular}



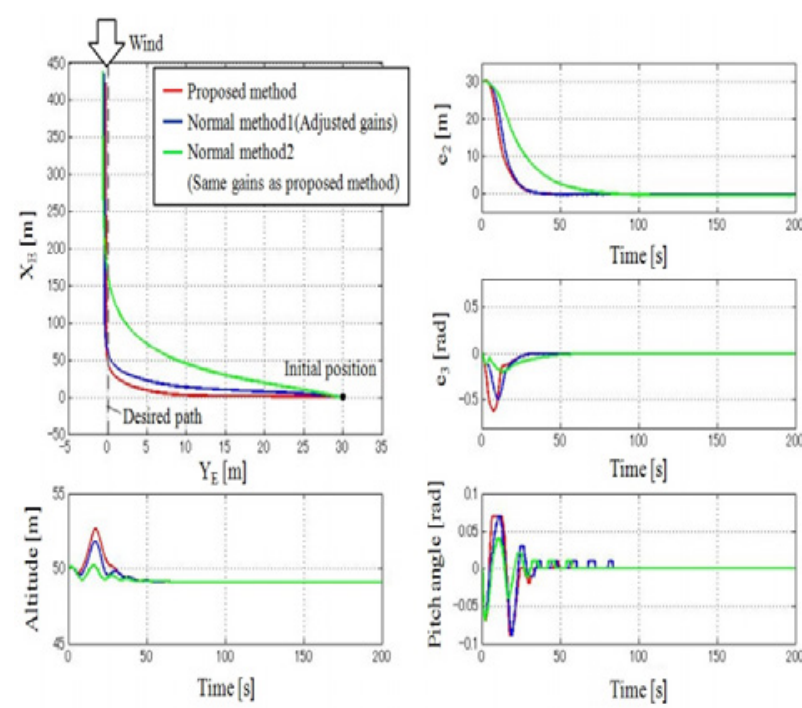

Fig. 24 Simulation results Case A: $V_{r e f}=5.0[\mathrm{~m} / \mathrm{s}]$
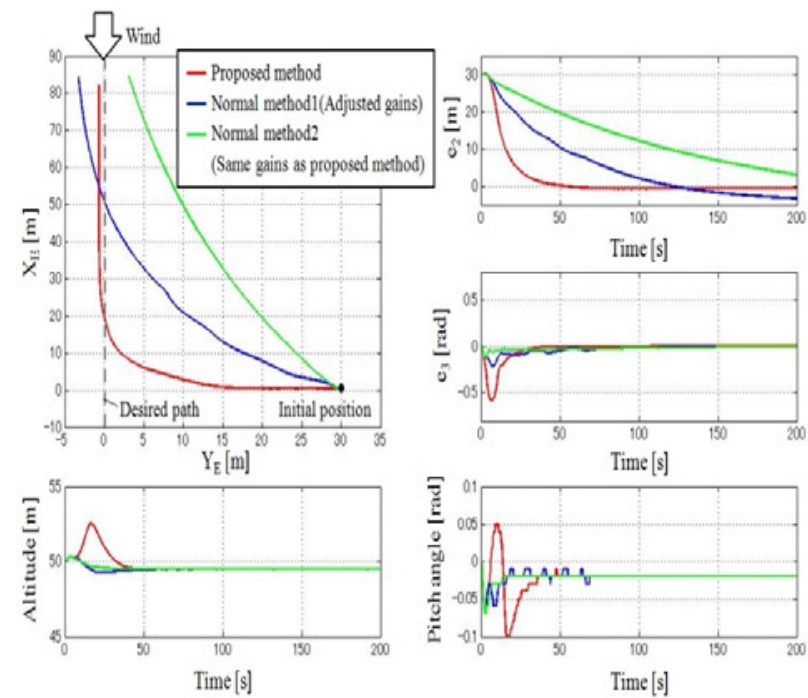

Fig. 26 Simulation results Case C: $V_{r e f}=1.0[\mathrm{~m} / \mathrm{s}]$
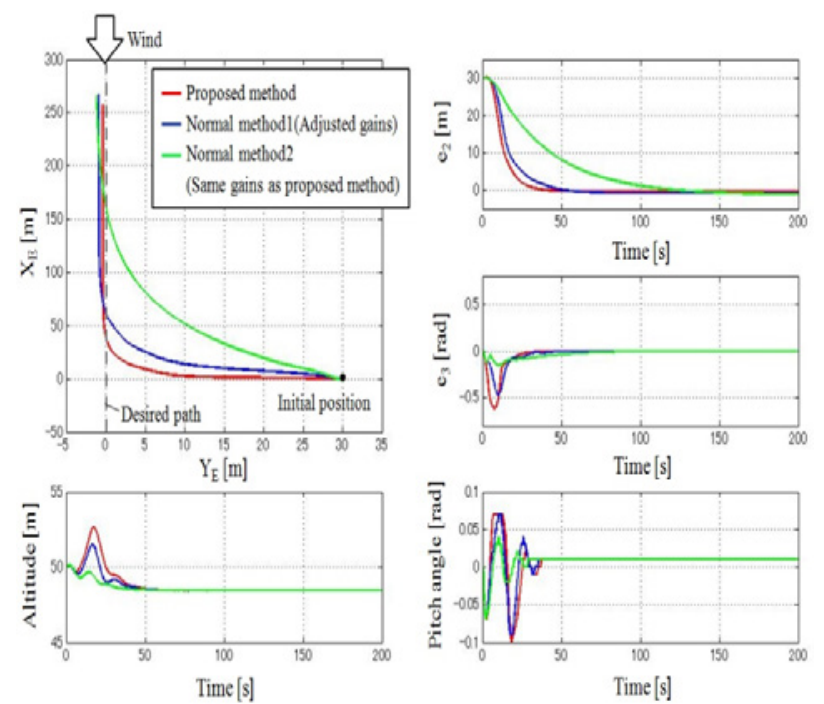

Fig. 25 Simulation results Case B: $V_{r e f}=3.0[\mathrm{~m} / \mathrm{s}]$
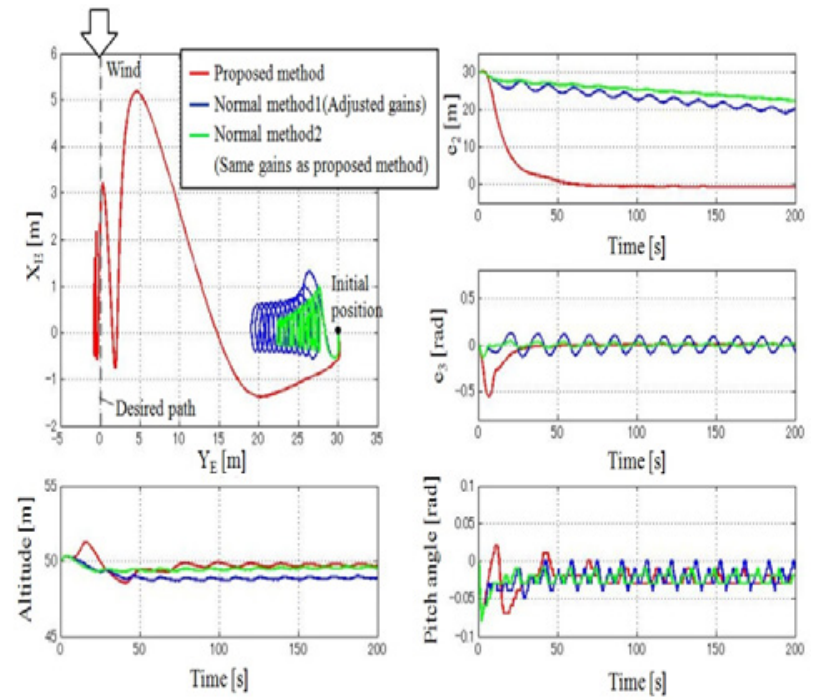

Fig. 27 Simulation results Case D: $V_{\text {ref }}=0.0[\mathrm{~m} / \mathrm{s}]$

文献

(1) 文部科学省研究開発局 独立行政法人防災科学技術研究所 NPO 法人国際レスキューシステム研究機構編, 大都 市大地震災害軽減化特別プロジェクト平成 17 年度成果報告書, (2006), 文部科学省研究開発局 独立行政法人防 災科学技術研究所 NPO 法人国際レスキューシステム研究機構.

(2) Fukao, T., Yuzuriha, A., Suzuki, T., Kanzawa, T., Oshibuchi, T., Osuka, K., Kohno, T., Okuyama, M., Tomoi, Y. and Nakadate, M., "Inverse Optimal Velocity Field Control of an Outdoor Blimp Robot - Blimp Surveillance Systems for Rescue -", Proceedings of IFAC 17th World Congress, (2008), pp.4374-4379.

(3) Khoury, G. A. and Gillet, J. D., Airship Technology, (1999), CAMBRIDGE UNIVERCITY PRESS.

(4) Azinheira, J. R., de Paiva, E., Ramos, J., Bueno, S. S., Bergerrnan, M. and Gomez, S. B. V., "Extended Dynamic Model for Aurora Robotic Airship", Proceedings of 14th AIAA Lighter-Than-Air Conference and Exibition, (2001).

(5) Kungi, P., Schlenker, M. and Krplin, B., "Research and testing activities with the solar powered airship LOTTE within the scope of the airship research group at the university of Stuttgart", Proceedings of AIAA 14th Lighter Than Air Convention and Exibition, (2001). 
(6) Turner, A., "Development of a semi-autonomous control system for the UVA solar airship AZTEC", Proceedings of 3rd International Airship Convention and Exhibition, (2001).

(7) Bestaoui, Y. and Hima, S., "Some insight in path planning of small autonomous blimps", Polish Arcademy of Sciences Transaction on Archives of Control Sciences, Vol. 11, N 3-4 (2001), pp.21-49.

(8) Hygounenc, E., Soueres, P. and Lacroix, S., "Developements on autonomous airship control at LAAS/CNRS", Proceedings of AIAA 14th Lighter Than Air Convention and Exhibition, (2001).

(9) Maekawa, S., Nakadate, M. and Takegawa, A., "Structures of the low-altitude stationary flight test vehicle", Proceedings of AIAA 5th Aviation, Technology, Integration, and Operations Conference, (2005), pp.662-666.

(10) Yoshida, T. and Fukao, T., "Dense 3D reconstruction using a rotational stereo camera", Proceedings of International Symposium on System Integration, (2011).

(11) 塩澤秀門, 吉田武史, 深尾隆則, “飛行船に搭載したレーザレンジファインダとカメラによる三次元モデル再 構成”, 計測自動制御学会関西支部若手研究特別発表会講演論文集, (2011), pp.119-122.

(12) 宮島才訓, 深尾隆則, 大須賀公一, 河野敬, “屋外型飛行船ロボットの角度場制御に関する研究”, 第 26 回日本口 ボット学会学術講演会講演論文集, (2008).

(13) Saiki, H., Fukao, T., Urakubo, T. and Kohno, T., "Hovering Control of Outdoor Blimp Robots Based on Path following”, Journal of Robotics and Mechatronics, Vol. 23, No. 2 (2011), pp.207-214.

(14) 岡村裕輝, 佐伯一夢, 深尾隆則, “屋外型飛行船ロボットの縦系制御”, 計測自動制御学会関西支部若手研究特別 発表会講演論文集, (2010), pp.53-56.

(15) 佐伯一夢, 深尾隆則, 浦久保孝光, 河野敬, “屋外型飛行船ロボットの風外乱下での飛行制御系設計法”, 第 16 回 ロボティクスシンポジア講演論文集, (2011), pp.365-372.

(16) 山田学, 佐藤真吾, 富塚誠義, “速度情報を必要としない劣駆動飛行船システムの大域的指数安定化と飛行実験”, 日本機械学会論文集 C 編, Vol. 75, No. 754 (2009), pp.1671-1679.

(17) 山田学, 多喜 康博, 舟橋 康行, “定常風に対する飛行船システムの大域的な位置と姿勢の制御”, 日本機械学会論 文集 C 編, Vol. 76, No. 767 (2010), pp.1770-1779.

（18）石崎溌雄, 光田寧, 佐野雄二, “風速変動の長周期成分について (2)”, 京都大学防災研究所年報, Vol. 12(A), (1969), pp.227-235.

(19) Samson, C., "Path following and time-varying feedback stabilization of a wheeled mobile robot", Proceedings of International Conference on Control, Automation, Robotics and Vision'92, (1993).

(20) Jiang, Z. P. and Nijimeijer, H., "Tracking control of mobile robots: A case study in backstepping”, Automatica, Vol. 33, (1993), pp.1393-1399.

(21) Kanayama, Y., Kimura, Y., Miyazaki, F. and Noguchi, T., "A stable tracking control method for an autonomous mobile robot", Proceedings of IEEE International Conference on Robotics and Automation, (1990), pp.384-389.

(22) Slotine, J. J. E. and Weiping, L., Applied Nonlinear Control, (1995), Prentice Hall.

(23) Nakadate, M., Kohno, T. and Okuyama, M., "On-going UAV R \& D at JAXA's Aviation Program Group - With Emphasis on LTA Flight Test -", Proceedings of International airship convention, (2008), pp.71165-71186.

(24) Kakegawa, S., Fukao, T. and Okuyama, M., "Aerodynamic characteristics of an airship with cruciform, x,and inverted-y fins - a wind tunnel experiment and estimation", Proceedings of 23th Asia-Pacific International Symposium on Aerospace Technology, (2009).

(25) 奥山政広, 深尾隆則, 岩崎昭人, “風洞試験による小型飛行船模型の空力特性”, 宇宙航空研究開発機構研究開発 資料 JAXA-RM-11-008, (2012). 